\title{
Has Fiscal Rules changed the Fiscal Behaviour of Union Government in India? Anatomy of Budgetary Forecast Errors in India
}

\author{
Lekha S Chakraborty ${ }^{1} \&$ Darshy Sinha ${ }^{1}$ \\ ${ }^{1}$ National Institute of Public Finance and Policy, New Delhi, India \\ Correspondence: Lekha S Chakraborty, Associate Professor, National Institute of Public Finance and Policy, 18/2 \\ Satsang Vihar Marg, Special Institutional Area, (Near JNU East Gate), A-17 Aruna Asafali Marg, New Delhi \\ 110067, India. Tel: 91-11- 011-2656-9303 (extension 111).
}

Received: May 2, 2018

doi:10.5430/ijfr.v9n3p75
Accepted: May 16, 2018

Online Published: June 13, 2018

URL: https://doi.org/10.5430/ijfr.v9n3p75

\begin{abstract}
We analyse the fiscal marksmanship of the macro-fiscal variables of Union Government ex-ante and ex-post to the formulation of fiscal rules in India. The fiscal marksmanship is the accuracy of budgetary forecasting. The fiscal rules have been legally mandated in India in the form of fiscal responsibility and budget management Act (FRBM Act) in 2003, with a criteria of fiscal-deficit to GDP threshold ratio of 3 per cent and gradual phasing out of revenue deficit. Using Theil's inequality coefficient $(\mathrm{U})$ based on the mean square prediction error, the paper estimates the magnitude of errors in the budgetary forecasts in India during the period ex-ante and ex-post to fiscal rules, and also decomposed the errors into biasedness, unequal variation and random components. The decomposition of errors is to analyze the source of error in both the regimes. Our results found that in both regimes, the proportion of error due to random variation has been significantly higher, which is beyond the control of the forecaster. In other words, the error due to bias of the policy maker in preparing the Union Budget has been negligible in the period ex-ante and ex-post to fiscal responsibility and budget management (FRBM) Act in India. The estimates also showed that the errors due to policy maker's bias has comparatively reduced in the regime ex-post to fiscal rules. The analysis related to efficiency of forecasts showed that no significant improvement in forecasts over time. This result has significant policy implications especially in the context of repeal of 2003 FRBM Act in India and the Union Government has announced clauses for a 'New FRBM Act' in India in the Finance Bill 2018.
\end{abstract}

Keywords: fiscal marksmanship, budget forecast errors, fiscal rules, rational expectations

JEL codes: C32 C53, E62, H50, H60

\section{Introduction}

Against the backdrop of fiscal rules - legally mandated fiscal responsibility and budget management (FRBM 2003) Act - in India, our paper explores the budget forecast errors of a period ex-ante and ex-post to the fiscal rules. The FRBM stipulates that fiscal deficit to GDP ratio should be maintained at 3 per cent, and revenue deficit should be zero. The objective of the paper is to analyse whether absence of fiscal rules led to either a bias or some systematic variations in budgetary forecast or the forecast errors were beyond the purview of forecaster, and also any disctinct change in fiscal behaviour in the Union Budget marksmanship ex-post to the fiscal rules.

Auerbach (2017) in the "Rethinking Macroeconomics" meeting held in Peterson Institute, has highlighted that many countries in recent years amended their existing fiscal rules. Even logical and well-written fiscal rules require justification, given that constraining a government's ability to practise fiscal policy has obvious disadvantages as well (Auerbach 2017). In India, the Finance Bill 2018 has incorporated a few clauses (clauses 207-10) to amend FRBM Act, 2003, with special reference to eliminate the reference to "revenue balance" and using fiscal deficit as an operational parameter (Chakraborty and Chakraborty, 2018).

In India, Union Budget has three stages - the announcement of Budget Estimate, (BE); after review and revision, government announces the Revised Estimate (RE) the next year and finally publishes the Actuals (actual spending) with a lag of one year or two. We analyse whether there is a sync between BE and RE, and between BE and Actuals or a significant deviation between these three. 
According to the theory of efficient markets, economic agents use all available information to form rational expectations. The rational expectations hypothesis asserts that information is scarce, and the economic system generally does not waste information and that expectations depend specifically on the structure of entire system (Note 1).

Fiscal marksmanship, the accuracy of budgetary forecasting, can be one important piece of such information the rational agents must consider in forming expectations. The significant variations between actual revenue and expenditure from the forecasted budgetary magnitudes could be an indicative of non-optimization or non-attainment of set objectives of fiscal policy.

In this context, the role of budget estimates needs to be emphasized as fiscal signals (Note 2). This point has gained much momentum especially when expectations are based, not on what has happened in the past, but on the data relating to future. That is, if expectations are rational rather than adaptive, it is the estimate of taxes and spending in any given budget - the ex-ante data, not the observed data, available only with a lag - that will be used by forward-looking private agents who base their decisions in whole or in part on fiscal variables (Morrison, 1986).

The wide variations in forecast errors have significant macroeconomic implications. For instance, excessive financing of deficits - seigniorage financing or bond financing - results if actual expenditure exceeds budgeted/expected expenditure. Similarly, cutbacks of crucial public expenditure - in particular, capital expenditure - results when actual revenue falls short of budgeted. The errors in budgetary forecast can occur due to endogenous and exogenous factors; which include overestimation/underestimation of buoyancy related to revenue and expenditure, poor assessment of GDP growth, price level; bad drought or monsoon failure, oil price shocks etc (Note 3). The paper examines the accuracy of budgetary forecasts of Union Government of India for the period ex-ante and ex-post to fiscal rules and analyses the systematic and random components from the partitioned forecast errors, before testing the forecasts for rational expectations.

The paper is divided into seven sections. Apart from Introduction, Section II briefly explores the theoretical and empirical survey of literature, while section III deals with the methodology of evaluation. Section IV interprets data, provides the estimates of fiscal marksmanship while section $\mathrm{V}$ estimates the sources of errors in the budgetary forecasts. Section VI provides the estimates of rational expectations while section VII concludes.

\section{Theoretical and Empirical Review of Literature}

Buiter and Patel (2011) have anaysed the fiscal rules in India, however the effect of fiscal rules on fiscal marksmanship in the context of India has not been analysed. Nitin and Roy (2017) have analysed the normative fiscal assessments of the Finance Commission (FC) of India, and realisation of fiscal policy with regard to Central Finances over the period 1990-2012, employing the Theil's inequality. Allan's (1965) was one of pioneering studies on errors in budgetary forecasts, which studied the accuracy of budget forecasts in the context of UK over the period of 1951-63. Davis (1980) was extended by Allan (1965) covering more time series, viz., 1951-78. These studies emphasized the need for accurate budget forecasts if fiscal policy was to be used to move the economy towards full employment without engendering excessive inflation. The analysis of the accuracy of budget estimates pertains to the impact of the economy on the budget rather than fiscal impact on the economy (Davis, 1980). Auld (1970) investigated the forecast errors in budgetary estimates in the context of Canada. In these studies, 'budget measures' rather than 'fiscal impact' measures are analysed.

The analyses on the accuracy of budgetary forecasts in the context of India are Paul and Rangarajan (1974), Asher (1978), Chakrabarty and Varghese (1982), Pattnaik (1990) and Bhattacharya and Kumari (1988). These studies are confined to the earlier decades and most of the studies has not looked into the sources of error components, but confined to the magnitude of errors. Asher (1998) examined the errors in the budget estimates and revised estimates of both revenue and expenditures of the Central Government of India during the period 1967-68 to 1975-76. The study revealed that both revenues and expenditures were grossly underestimated and the error for expenditures had been greater. He emphasized the need to increase the technical sophistication of the forecasting process as it has wider implications not only for stabilization policy but also for the credibility of the political process and for the strategy of planned development itself. Chakrabarty and Varghese (1982) revealed that revenues were underestimated, expenditures too were, more often than not, underestimated during the period 1970-71 to 1979-80. The study found that there was no specific trend in the forecasting errors and there was no reflection of these errors on the formulation of budgets. The study also made a policy recommendation that in order to reduce the significant errors in the estimates, forecasts should be linked to movements of exogenous variables in the economy. On revenue side, through fitting tax rate functions, Srivastava (1975) suggested a tax-revenue forecasting in a partial equilibrium framework and estimated non-corporate income tax revenue forecast in India for the period 1961-62 to 1972-73. 
Bhattacharyya and Kumari (1988) has tested the budgetary forecasts for rational expectations in the context of India and also tested for the efficiency of budget forecasts over time; in addition to the magnitude and sources of errors in budgetary forecast. Their study revealed that neither budget estimates nor revised estimates were based on rational expectations of forecasting during sixties, and the estimates were not even unbiased predictors of actual receipts and expenditure. The biases in the forecasts worsened in seventies and eighties when compared to sixties, the study noted. Concomitant with this study, the present study looks into the magnitude and sources of errors in the budgetary forecasts for the nineties and test for rational expectations.

\section{Methodological Issues}

In the paper, Theil's inequality coefficient (U) is used to analyze the measure of accuracy of the budget forecasts. Theils' inequality coefficient is based on the mean square prediction error. The forecast error of Theil (1958) is defined as:

$$
\mathbf{U}_{1}=\frac{\sqrt{1 / n \sum\left(P_{t}-A_{t}\right)^{2}}}{\sqrt{1 / n \sum P_{t}^{2}}+\sqrt{1 / n \sum A_{t}^{2}}}
$$

where

$\mathrm{U}_{1}=$ inequality coefficient

$\mathrm{P}_{\mathrm{t}}=$ Predicted value

$\mathrm{A}_{\mathrm{t}}=$ Actual value

$\mathrm{n}=$ the number of years

This inequality coefficient ranges from zero to one. When $P_{t}=A_{t}$ for all observations (a perfect forecast), $U_{1}$ equals zero. When there is non-positive proportionality between the $P_{t}$ and $A_{t}, U$ equals to one. $N$ is 13 years (the actual number of years under study which is 13 years).

Theils' second equation for inequality coefficient, which uses a revised measure of forecast error. Theil's (1966 and 1971) revised measure of inequality is as follows.

$$
\mathbf{U}_{2}=\frac{\sqrt{1 / n \sum\left(P_{t}-A_{t}\right)^{2}}}{\sqrt{1 / n \sum A_{t}^{2}}}
$$

This measure has an advantage that denominator does not contain $\mathrm{P}$ and the inequality coefficient does not depend on the forecast. In perfect forecast, $\mathrm{U}_{2}$ equals to zero. $\mathrm{U}_{2}$ does not have an upper bound. However, if $\mathrm{P}$ and $\mathrm{A}$ are defined in terms of changes then no change forecast $\left(p_{t}=0\right.$ for all $\left.t\right)$ would lead to a value of one. When $U_{2}$ equals unity, the forecast has the same accuracy that would have been achieved by means of a "naïve no change extrapolation' (Theil, 1971). As Theil (1971:29) noted, it is "tantamount to saying that this is possible to do considerably worse than by extrapolating on a no-change basis".

A more rigorous measure of Theil's inequality statistics is also used, by incorporating the lags in the actuals and the difference of predicted value from the lag of the actuals to capture the magnitude of error.

$$
\mathbf{U}_{\mathbf{3}}=\sqrt{\frac{1 / n \sum[P t-a t]^{2}}{1 / n \sum[P t]^{2}+1 / n \sum[a t]^{2}}}
$$

Where $\mathrm{a}=\mathrm{A}_{\mathrm{t}}-\mathrm{A}_{\mathrm{t}-1}$

$\mathrm{P}_{\mathrm{t}}=\mathrm{P}_{\mathrm{t}}-\mathrm{A}_{\mathrm{t}-1}$

$\mathrm{n}=$ no: of years

After analyzing the magnitude of error, partitioned forecast error has been applied to budgetary estimates for the fiscal years 1990-91 to 2003-04. The mean square prediction error $\left(\mathrm{U}_{1}\right)$ has been decomposed in order to indicate systematic and random sources of error. The systematic component is further divided into the proportion of the total forecast error due to bias and the proportion of total forecast error attributable to unequal variation. The derivation of equation 4 is given in detail in Davis (1980).

$$
\mathbf{1}=\frac{\overline{(P}-\bar{A})^{2}}{1 / n \sum\left(P_{t}-A_{t}\right)^{2}}+\frac{(S p-S a)^{2}}{1 / n \sum\left(P_{t}-A_{t}\right)^{2}}+\frac{2(1-r) S p \cdot S a}{1 / n \sum\left(P_{t}-A_{t}\right)^{2}}
$$


In equation (4), $\mathrm{P}$ and $\mathrm{A}$ are mean predicted and mean actual changes respectively; $\mathrm{Sp}$ and $\mathrm{Sa}$ are the standard deviations of predicted and actual values respectively; and $r$ is the coefficient of correlation between predicted and actual values.

The first expression of RHS of equation (4) is the proportion of the total forecast error due to bias. It represents a measure of proportion of error due to over prediction or under prediction of the average value. The second expression of the RHS of equation (4) is the proportion of total forecast error attributable to unequal variation. In other words, it measures the proportion of error due to over prediction or under prediction of the variance of the values. The third expression on the RHS of the equation (4) measures the proportion of forecasting error due to random variation.

The first two sources of error are systematic. Presumably they can be reduced by the improved forecasting techniques; while the random component is beyond the controller of the forecaster (Intriligator, 1978; Pindyck and Rubenfield, 1998; Theil, 1966). In the paper, partitioned forecast error will be applied to budgetary estimates for the fiscal years in the prior decade.

\section{Interpreting Data}

Budgetary data in India is published in three stages: (a) Budget Estimates (b) Revised Estimates and (c) Actuals. Budget estimates are released at the time of budget presentation. It presents expenditure estimates in the form of Ministry wise demand for Grants and in turn categorized into revenue account and capital account (Note 4).

Table 1. Errors in forecasting revenue receipts, ex-ante and ex-post to fiscal rules

\begin{tabular}{cccc}
\hline & \multicolumn{2}{c}{ Revenue Receipts } & \\
Actual (in Rs. cr.) & \%Error (BE) & \% Error (RE) \\
\hline $1990-91$ & 54954 & 5.43 & 4.42 \\
$1991-92$ & 66047 & 2.24 & 0.76 \\
$1992-93$ & 74128 & 2.10 & 5.60 \\
$1993-94$ & 75453 & 11.60 & 0.94 \\
$1994-95$ & 91083 & -5.49 & -2.54 \\
$1995-96$ & 110130 & -8.48 & 0.06 \\
$1996-97$ & 126279 & 3.22 & 3.57 \\
$1997-98$ & 133901 & 14.37 & 3.45 \\
$1998-99$ & 149510 & 8.35 & 5.45 \\
$1999-00$ & 181513 & 0.73 & -1.11 \\
$2000-01$ & 192624 & 5.74 & 7.03 \\
$2001-02$ & 201449 & 15.04 & 5.52 \\
$2002-03$ & 231748 & 5.76 & 2.24 \\
$2003-04$ & 263878 & -3.77 & -0.32 \\
$2004-05$ & 306013 & 1.08 & -1.67 \\
$2005-06$ & 347462 & 1.08 & 0.29 \\
$2006-07$ & 434387 & -7.12 & -2.55 \\
$2007-08$ & 541864 & -10.23 & -3.09 \\
$2008-09$ & 540259 & 11.60 & 4.06 \\
$2009-10$ & 572811 & 7.28 & 0.78 \\
$2010-11$ & 788471 & -13.48 & -0.59 \\
$2011-12$ & 751437 & 5.12 & 2.07 \\
$2012-13$ & 879232 & 6.42 & -0.84 \\
$2013-14$ & 1014724 & 4.10 & 1.43 \\
$2014-15$ & 1101472 & 8.02 & 2.25 \\
$2015-16$ & 1195025 & -4.47 & -1.39 \\
$2016-17$ & 1374203 & 0.21 & 3.59 \\
\hline
\end{tabular}

Source: (Basic data), Budget Documents, Ministry of Finance, Government of India 
The results showed that both revenue and expenditure components of the budget revealed errors in forecast. Table 1 presents the actual revenue receipts along with the forecasting errors during the period ex-ante and ex-post to fiscal rules implemented in 2003-04. The analysis showed that broadly revenue receipts has been overestimated for most of the years, in both the periods (Table 1).

Table 2. Percentage of error in estimates of expenditure budget

\begin{tabular}{|c|c|c|c|c|c|c|}
\hline & \multicolumn{3}{|c|}{ Revenue Expenditure } & \multicolumn{3}{|c|}{ Capital Expenditure } \\
\hline & $\begin{array}{l}\text { Actual } \\
\text { (in Rs. cr.) }\end{array}$ & $\begin{array}{l}\% \\
\text { (Budget) }\end{array}$ & $\begin{array}{c}\text { Error \% Error } \\
\text { (Revised } \\
\text { Budget) }\end{array}$ & $\begin{array}{l}\text { Actual } \\
\text { (in Rs. cr.) }\end{array}$ & $\begin{array}{l}\% \\
\text { (Budget) }\end{array}$ & $\begin{array}{c}\text { Error } \% \text { Error } \\
\qquad \begin{array}{c}\text { (Revised } \\
\text { Budget) }\end{array}\end{array}$ \\
\hline 1990-91 & 73516 & -3.46 & 1.97 & 31800 & -10.88 & -0.15 \\
\hline 1991-92 & 82308 & -1.12 & 1.61 & 29122 & 10.02 & 1.20 \\
\hline $1992-93$ & 92702 & -3.38 & 2.46 & 29916 & -1.33 & -0.56 \\
\hline 1993-94 & 108169 & -5.85 & 1.90 & 33684 & -12.47 & -0.11 \\
\hline 1994-95 & 122112 & -2.70 & 0.65 & 38627 & -14.86 & 1.92 \\
\hline $1995-96$ & 139860 & -2.53 & 2.62 & 38415 & -6.75 & 2.78 \\
\hline $1996-97$ & 158933 & 1.82 & 0.03 & 42074 & 1.82 & 2.94 \\
\hline 1997-98 & 180350 & 1.70 & 1.03 & 51718 & -5.70 & 2.57 \\
\hline 1998-99 & 217419 & -3.38 & 0.33 & 61947 & -6.59 & 2.95 \\
\hline 1999-00 & 249109 & -4.87 & 1.58 & 48975 & -4.25 & 3.53 \\
\hline $2000-01$ & 277858 & 1.17 & 2.04 & 47753 & 20.18 & 8.87 \\
\hline 2001-02 & 301611 & 2.97 & 0.89 & 60842 & 6.27 & -1.17 \\
\hline $2002-03$ & 339627 & 0.25 & 0.60 & 60769 & 14.91 & 2.63 \\
\hline 2003-04 & 362140 & 1.13 & 0.21 & 109228 & -33.56 & 1.96 \\
\hline 2004-05 & 384351 & 0.30 & 0.45 & 113331 & -27.35 & 5.64 \\
\hline $2005-06$ & 436761 & 2.23 & 0.81 & 66362 & 2.22 & 3.09 \\
\hline 2006-07 & 583387 & -16.32 & -13.13 & 68778 & 10.21 & 8.86 \\
\hline 2007-08 & 594433 & -6.15 & 19.34 & 118238 & 3.71 & 2.16 \\
\hline 2008-09 & 793798 & -5.41 & 1.22 & 90158 & 2.89 & 8.15 \\
\hline $2009-10$ & 911809 & -1.60 & -0.60 & 112678 & 9.70 & 2.23 \\
\hline 2010-11 & 1040723 & -7.88 & 1.24 & 156605 & -4.20 & 4.02 \\
\hline 2011-12 & 1145785 & -4.24 & 1.41 & 158580 & 1.25 & -1.14 \\
\hline $2012-13$ & 1243514 & 3.43 & 1.57 & 166858 & 22.75 & 0.54 \\
\hline 2013-14 & 1371772 & 4.69 & 2.02 & 187675 & 22.09 & 1.72 \\
\hline 2014-15 & 1214441 & 29.12 & -0.10 & 196682 & 15.30 & -2.19 \\
\hline $2015-16$ & 1537761 & -14.67 & 0.64 & 253022 & -4.58 & -6.05 \\
\hline 2016-17 & 1690584 & 2.39 & 2.60 & 284610 & -13.21 & -1.67 \\
\hline
\end{tabular}

Source: (Basic data), Budget Documents, Ministry of Finance, Government of India

On the expenditure side, both revenue and capital expenditure has been grossly underestimated with respect to BE and actuals, while overestimated in case of RE and actuals (Table 2). The disaggregated level of analysis revealed that the degree of errors in forecasting receipts was relatively higher than expenditure in the period 1990-91 to 2016-17. The pattern of error thus gave a systemic upward increase in the estimation of deficit of the government.

The forecasting errors in revenue deficit, fiscal deficit and primary deficit are shown separately in Table 3, with respect to budget estimates and revised estimates. 
Table 3. Forecasting errors in deficit ex-ante to fiscal rules

\begin{tabular}{|c|c|c|c|c|c|c|c|c|c|}
\hline & \multicolumn{3}{|c|}{ Revenue Deficit } & \multicolumn{3}{|c|}{ Fiscal Deficit } & \multicolumn{3}{|c|}{ Primary Deficit } \\
\hline & $\begin{array}{l}\text { Actual } \\
\text { (in Rs. cr.) }\end{array}$ & $\begin{array}{l}\% \text { Error } \\
\text { (Budget) }\end{array}$ & $\begin{array}{l}\% \text { Error } \\
\text { (Revised } \\
\text { Budget) }\end{array}$ & $\begin{array}{l}\text { Actual } \\
\text { (in Rs. cr.) }\end{array}$ & $\begin{array}{l}\% \text { Error } \\
\text { (Budget) }\end{array}$ & $\begin{array}{l}\% \text { Error } \\
\text { (Revised } \\
\text { Budget) }\end{array}$ & $\begin{array}{l}\text { Actual } \\
\text { (in Rs } \\
\text { cr.) }\end{array}$ & $\begin{array}{l}\% \text { Erro } \\
\text { s. (Budget) }\end{array}$ & $\begin{array}{l}\text { \% Error } \\
\text { (Revised } \\
\text { Budget) }\end{array}$ \\
\hline 1990-91 & 18562 & -29.79 & -5.26 & 44650 & -17.59 & -2.95 & 22800 & -30.07 & -5.79 \\
\hline 1991-92 & 16261 & -14.80 & 5.04 & 36325 & 3.86 & 4.04 & 9762 & 5.28 & 7.99 \\
\hline 1992-93 & 18574 & -25.26 & -10.09 & 40173 & -14.35 & -8.59 & 9138 & -73.65 & -53.80 \\
\hline 1993-94 & 32716 & -46.11 & 4.10 & 60257 & -38.66 & -2.83 & 23562 & -104.42 & -10.66 \\
\hline 1994-95 & 31029 & 5.47 & 10.00 & 57704 & -4.83 & 5.77 & 13655 & -34.71 & 24.75 \\
\hline 1995-96 & 29730 & 19.55 & 12.11 & 60243 & -4.33 & 6.25 & 10212 & -44.83 & 17.61 \\
\hline 1996-97 & 32654 & -3.61 & -13.62 & 66733 & -6.69 & -5.40 & 7255 & -68.77 & -36.17 \\
\hline $1997-98$ & 46449 & -34.84 & -5.95 & 88937 & -26.40 & -2.91 & 23300 & -110.93 & -11.39 \\
\hline 1998-99 & 67909 & -29.22 & -10.95 & 113349 & -19.69 & -8.48 & 35467 & -54.82 & -25.31 \\
\hline 1999-00 & 67596 & -19.8961 & 8.78 & 104717 & -23.6466 & 3.99 & 14468 & -155.60 & 20.77 \\
\hline 2000-01 & 85234 & -9.16 & -9.23 & 118816 & -6.35 & -5.76 & 19502 & -48.68 & -42.03 \\
\hline 2001-02 & 100162 & -21.31 & -8.42 & 140955 & -17.48 & -6.55 & 33495 & -88.02 & -26.96 \\
\hline 2002-03 & 107879 & -11.59 & -2.94 & 131306 & 3.21 & 10.78 & 13502 & 34.31 & 120.73 \\
\hline 2003-04 & 98262 & 14.28 & 1.63 & 123272 & 24.63 & 7.16 & -816 & -3827.21 & -1025.00 \\
\hline 2004-05 & 78339 & -2.77 & 8.71 & 125202 & 9.75 & 11.21 & -1732 & -556.52 & -869.40 \\
\hline 2005-06 & 92299 & 3.26 & -0.52 & 146435 & 3.22 & -0.18 & 13805 & 24.59 & 16.94 \\
\hline 2006-07 & 80222 & 5.62 & 4.01 & 142573 & 4.29 & 6.84 & -7699 & -215.12 & -179.70 \\
\hline 2007-08 & 52569 & 35.97 & 20.77 & 126912 & 18.94 & 13.19 & -44118 & -81.76 & -35.81 \\
\hline 2008-09 & 253539 & -78.23 & -4.84 & 336992 & -60.45 & -3.11 & 144788 & -139.73 & -7.57 \\
\hline $2009-10$ & 338998 & -16.60 & -2.93 & 418482 & -4.18 & -1.06 & 205389 & -14.56 & -5.28 \\
\hline 2010-11 & 252252 & 9.62 & 6.97 & 373591 & 2.09 & 7.34 & 139569 & -4.89 & 14.81 \\
\hline 2011-12 & 394349 & -22.08 & 0.15 & 515991 & -20.00 & 1.16 & 242841 & -40.36 & 1.45 \\
\hline $2012-13$ & 364282 & -3.80 & 7.40 & 490190 & 4.77 & 6.27 & 177020 & 9.50 & 15.38 \\
\hline 2013-14 & 357048 & 6.38 & 3.71 & 502858 & 7.88 & 4.31 & 128604 & 33.60 & 12.34 \\
\hline 2014-15 & 365519 & 3.51 & -0.83 & 510726 & 4.00 & 0.37 & 108282 & -3.80 & -6.47 \\
\hline $2015-16$ & 342736 & 15.10 & -0.33 & 532791 & 4.29 & 0.43 & 91132 & 9.19 & 1.47 \\
\hline 2016-17 & 316381 & 11.90 & -1.70 & 535618 & -0.32 & -0.25 & 54904 & -24.90 & -6.74 \\
\hline
\end{tabular}

Source: (Basic data), Budget Documents, Ministry of Finance, Government of India

The root mean square errors of revenue receipts, expenditure and deficits are given in Table 4. RMSE has two limitations. It does not distinguish between under and over predictions. Also, there is no theoretical upper bound for RMSE. Based on root mean square error, Theil's inequality coefficient is calculated. The budget estimates are considered as the expectations of government revenue, expenditure and deficit.

Table 4. Root mean square error (RMSE) for Central Budget Forecasting

\begin{tabular}{lll}
\hline & RMSE (BE, Actual) & RMSE (RE, Actual) \\
\hline Revenue Receipts & 12094.52 & 6009.45 \\
Capital Receipts & 13574.43 & 5568.32 \\
Revenue Expenditure & 5358.03 & 2607.06 \\
Capital Expenditure & 11348.71 & 2233.08 \\
Revenue Deficit & 11915.54 & 4720.94 \\
Fiscal Deficit & 15772.39 & 6599.16 \\
Primary Deficit & 16624.63 & 6854.36 \\
\hline
\end{tabular}

Source: (Basic data), Budget Documents, Ministry of Finance, Government of India 
Like RMSE, Theil's U also cannot distinguish between under or over prediction. However, the magnitude of error can be examined from the inequality coefficients (Us). U will be zero when the forecast is perfect. The three inequality coefficients estimated using variants of Theils' $U$ are given in Table 5.

Table 5. Theil's inequality statistic (u) for central government budget forecasting ex-ante to fiscal rules

\begin{tabular}{lllllll}
\hline EX-ANTE FISAL RULES & \multicolumn{3}{l}{ Theils' U (BE, Actual) } & \multicolumn{3}{l}{ Theils' U (RE, Actual) } \\
\hline & U1 & U2 & U3 & U1 & U2 & U3 \\
Revenue Receipts & 0.04 & 0.08 & 0.40 & 0.02 & 0.04 & 0.23 \\
Capital Receipts & 0.06 & 0.12 & 0.59 & 0.03 & 0.06 & 0.25 \\
Revenue Expenditure & 0.01 & 0.02 & 0.16 & 0.01 & 0.01 & 0.08 \\
Capital Expenditure & 0.11 & 0.21 & 0.66 & 0.02 & 0.05 & 0.22 \\
Revenue Deficit & 0.10 & 0.19 & 0.99 & 0.04 & 0.08 & 0.35 \\
Fiscal Deficit & 0.09 & 0.17 & 0.89 & 0.04 & 0.07 & 0.38 \\
Primary Deficit & 0.52 & 0.85 & 0.83 & 0.18 & 0.34 & 0.44 \\
\hline
\end{tabular}

Source: (Basic data), Budget Documents, Ministry of Finance, Government of India

Capital budget revealed more forecast errors than Revenue budget. In other words, capital receipts and capital expenditure have shown relatively more forecasting errors than revenue receipts and revenue expenditure. In the backdrop of Fiscal Responsibility and Budget Management Act in India, the emphasis has been given to contain revenue deficit. The results revealed that equally important emphasis needs to be given on the Capital Account of the budget. Primary deficit showed comparatively higher forecast errors (Table 5 and 6) ex-ante and ex-post to fiscal rules. The Theil's U showed that the magnitude of errors reduced ex-post to the fiscal rules.

Table 6: Theil's inequality statitics ( $U$ ) for central government budgets forecasting ex-post to fiscal rules

\begin{tabular}{llc}
\hline & U1 & $\begin{array}{c}\text { Theils' U (BE, Actual) } \\
\text { U2 }\end{array}$ \\
\hline & & \\
Revenue Receipts & 0.01 & 0.02 \\
Revenue Expenditure & 0.02 & 0.03 \\
Capital Expenditure & 0.02 & 0.04 \\
Revenue Deficit & 0.03 & 0.06 \\
Fiscal Deficit & 0.02 & 0.04 \\
Primary Deficit & 0.07 & 0.14 \\
\hline
\end{tabular}

Source: (Basic data), Budget Documents, Ministry of Finance, Government of India

The accuracy of budget estimates for the fiscal deficit might have benefited from some offsetting errors between the forecasts of revenue and expenditure. Fiscal deficit, the net borrowing requirement of the Central government, represents the difference between total expenditure and non-debt creating receipts. Relatively small errors in forecasting fiscal deficit can cause large errors in budget estimates of the borrowing requirement. However it is to be noted that the magnitude of errors in the budget estimates of net borrowing requirement is a matter of grave concern in the context of the increasing attention paid to its aggregate in the policy making and its significance for macroeconomic stability. Deducting the interest payment from fiscal deficit, the primary deficit is computed and the forecast error in primary deficit is also analysed. The magnitude of error has increased significantly when interest payment was deducted from fiscal deficit. In other words, error component is very high in the primary fiscal expenditure as significant share of which is discretionary in nature.

\section{Partitioning the Sources of Error}

The sources of errors can be divided into two: (a) errors on account of miscalculation and wrong judgement and (b) errors on account of unanticipated and exogenous shocks. The former can occur partly on account of wrong judgement of key economic variables like national income, investment, savings, inflation etc which influences 
government revenue and expenditure; and partly on account of improper estimation of key parameters of budgeting, like tax and expenditure elasticities (Bhattacharya and Kumari, 1988). Table 7 showed that the magnitude of bias component has reduced ex-post to the fiscal rules. In other words, the forecast errors were largely due to random factors for all macro-fiscal variables.

Table 7. Partitioning the error components

\begin{tabular}{llll}
\hline EX_ANTE FISCALRULES & Bias & Unequal variation & Random \\
Revenue Receipts & 0.24 & 0.07 & 0.69 \\
Capital Receipts & 0.45 & 0.14 & 0.41 \\
Revenue Expenditure & 0.05 & 0.15 & 0.80 \\
Capital Expenditure & 0.06 & 0.22 & 0.72 \\
Revenue Deficit & 0.36 & 0.01 & 0.63 \\
Fiscal Deficit & 0.31 & 0.01 & 0.68 \\
Primary Deficit & 0.32 & 0.00 & 0.67 \\
\hline EX_POST FISCAL RULES & Bias & Unequal variation & Random \\
Revenue Receipts & 0.01 & 0.04 & 0.95 \\
Revenue Expenditure & 0.00 & 0.31 & 0.69 \\
Capital Expenditure & 0.00 & 0.02 & 0.98 \\
Revenue Deficit & 0.04 & 0.01 & 0.96 \\
Fiscal Deficit & 0.02 & 0.01 & 0.97 \\
Primary Deficit & 0.05 & 0.02 & 0.93 \\
\hline
\end{tabular}

Source: (Basic data), Budget Documents, Ministry of Finance, Government of India

The decomposition of error reveals that the proportion of error due to random variation has been significantly higher, leaving less scope for the elimination of systematic error (Table 7). It is to be noted that there is no specific trend in the forecasting errors, which reveals that budgetary estimates are made not based on adaptive expectations. Though the proportion of error in the forecast due to bias and unequal variation is relatively less, better forecasts based on the buoyancy estimates of revenue and expenditure as well as periodic assessment of the stochastic errors of the budgetary forecast may improve the efficiency and reliability of budgetary forecasts. The decomposition of errors at the subnational public deficits across 29 states in India is also crucial and the analysis shows the same patterns of errors (Chakraborty and Shrestha, 2018).

\section{Testing for Rational Expectations}

While testing the rational expectations, the necessary condition is that the forecast $(\mathrm{P})$ should be an unbiased predictor of actual (A) (Muth, 1961). The sufficient condition is that the predicted error must be uncorrelated with the historical information, which can be tested whether the lagged value of the actuals is related to the present value of actuals (Lovell, 1986; Bhattacharyya and Kumari, 1988). In other words, the rational expectations hypothesis can be tested by the following equation:

$$
A_{t}=\alpha+\beta P_{t}+\gamma A_{t-1}+\mu_{t}
$$

Where,

$\mathrm{A}_{\mathrm{t}}=$ Error

$\mathrm{P}_{\mathrm{t}}=$ Predicted Value

The condition for Rational Expectations would be satisfied if:

$\alpha=0$;

$\beta=1$;

$\gamma=0$

and $\rho E_{t} \cdot P_{t}=0$ 
The equation (5) and (6) are estimated through OLS, checking for serial correlation. However, Durbin Watson statistics was near 2 in all models, hence we have not included AR(1) models.

According to Muth (1961), the forecast is rational if it is not only an unbiased predictor of the actual but also the forecast error is uncorrelated with the predicted value, which implies that the correlation coefficient $\rho\left(\mathrm{E}_{\mathrm{t}} . \mathrm{P}_{\mathrm{t}}\right)$ should be zero. Table 8 presents the coefficients of the test of rationality and the coefficients revealed that rational expectations hypothesis is invalid in the case of fiscal variables in India during the nineties. In other words, neither receipts nor expenditure forecasts turn - both in revenue and capital budget- out to be the rational expectations of actual.

Table 8. Testing rational expectations

\begin{tabular}{llllll}
\hline Variable & $\boldsymbol{\alpha}$ & $\boldsymbol{\beta}$ & $\boldsymbol{\gamma}$ & $\mathbf{R}^{2}$ & $\boldsymbol{\rho}$ \\
\hline BE-Actuals & & & & & \\
Revenue Receipts & 3593.76 & 0.04 & $1.05^{*}$ & 0.98 & -0.31 \\
Capital Receipts & 831.66 & $1.06^{*}$ & 0.03 & 0.97 & 0.43 \\
Revenue Expenditure & -795.48 & $0.91^{*}$ & 0.09 & 0.99 & -0.43 \\
Capital Expenditure & -7235.62 & $1.08^{*}$ & 0.13 & 0.71 & 0.21 \\
Revenue Deficit & 6566.41 & 0.20 & 0.79 & 0.92 & -0.05 \\
Fiscal Deficit & 11683.66 & 0.36 & 0.58 & 0.90 & -0.31 \\
Primary Deficit & 16788.07 & -0.13 & 0.06 & 0.62 & -0.76 \\
RE-Actuals & & & & & \\
Revenue Receipts & 296.98 & $1.23^{*}$ & -0.30 & 0.99 & -0.40 \\
Capital Receipts & -1281.00 & $1.15^{*}$ & -0.14 & 0.99 & 0.23 \\
Revenue Expenditure & 6423.41 & $0.80^{*}$ & 0.21 & 0.99 & -0.17 \\
Capital Expenditure & 951.71 & $1.04^{*}$ & -0.09 & 0.99 & -0.06 \\
Revenue Deficit & -1817.06 & $1.24^{*}$ & -0.19 & 0.98 & 0.32 \\
Fiscal Deficit & 1298.44 & $1.33^{*}$ & -0.36 & 0.99 & -0.09 \\
Primary Deficit & 7959.37 & 1.05 & -0.42 & 0.64 & -0.22 \\
\hline
\end{tabular}

Source: (Basic data), Budget Documents, Ministry of Finance, Government of India

The results showed that coefficients of $\propto$ of all macrovariables are significantly different from zero; while $\beta$ is closer to one, but not significant in most of the cases, which showed the bias in forecasting. It is also revealed that revenue receipts seems to be underestimated by a constant amount every year, which is reflected in Similarly capital receipts and capital expenditure seem to be underestimated by a fixed rate, as in relation to budget and revised forecast. In the budget estimates, the correlation coefficient, $\rho$, greater than one, (that is, $\rho>1$ ), for capital receipts and capital expenditure signifies that the forecast errors of capital receipts and capital revenue are correlated with respective budget forecast. In the revised estimates, revenue expenditure is simultaneously underestimated by a constant amount (and overestimated by fixed rate). It is also to be noted that $\gamma$, which is the partial derivative of $A_{t}$ with respect to $A_{t-1}$, given $P_{t}$ is are not significant for all variables except revenue receipts. However, in case of revenue receipts also, $\gamma$ is significantly different from zero. Thus the coefficients in Table 8 suggests that neither BE nor RE are forecast based on the rational expectations of actual revenue and expenditure. Fscal deficit and revenue deficit in revised budgetary forecasts are underestimated by a fixed rate, as the coefficient is greater than one and significant.

The budgetary forecasts did not fulfil the necessary condition for rational expectations; that is, the forecast should be an unbiased predictor of actuals. As is not equal to zero and is significantly different from one; forecasts are not unbiased. The sufficient condition for rational expectations that the predicted error must be uncorrelated with the historical information is also ruled out as $\gamma$ is significant different from zero.

Finally, we examine whether the efficiency of budgetary forecasts improves over time or not. This can be examined by estimating the following function:

$$
Q_{t}=\delta+\theta T+\xi_{t}
$$

where, 
$Q_{t}=\frac{100 E_{t}}{A_{t}}$

$\mathrm{T}=$ linear time trend

Table 9. Efficiency of budgetary forecasts

\begin{tabular}{lllllll}
\hline & $\mathbf{B E}$ & \multicolumn{3}{c}{$\mathbf{R E}$} \\
\hline Variables & $\boldsymbol{\delta}$ & $\boldsymbol{\theta}$ & $\mathbf{R}^{2}$ & $\boldsymbol{\delta}$ & $\boldsymbol{\theta}$ & $\mathbf{R}^{\mathbf{2}}$ \\
Revenue Receipts & -2.577 & -0.201 & 0.014 & -2.133 & -0.053 & 0.006 \\
Capital Receipts & 6.669 & 0.208 & 0.007 & -3.644 & 0.451 & 0.085 \\
Revenue Expenditure & $4.035 *$ & $-0.362 *$ & 0.296 & $-2.107 *$ & $0.112 *$ & 0.287 \\
Capital Expenditure & 4.582 & -0.187 & 0.003 & -0.585 & -0.183 & 0.092 \\
Revenue deficit & $24.331 *$ & -1.262 & 0.081 & $203.453 *$ & $-6.085 *$ & 0.453 \\
Fiscal deficit & $18.962 *$ & -1.036 & 0.093 & 1.888 & -0.131 & 0.008 \\
Primary deficit & 103.482 & -9.303 & 0.129 & 21.449 & -2.667 & 0.069 \\
\hline
\end{tabular}

Source: (Basic data), Budget Documents, Ministry of Finance, Government of India

The efficiency of forecasting improves if $\theta<0$.The illustrative results suggest that all the variables except revenue expenditure in budget forecasts have no significant improvement over time (Table 9). However, the forecasts of revenue expenditure in terms of revised estimates have shown deterioration over time. The serial autocorrelations are not there as the Durbin Watson statistics of all the estimations was around 2. Hence we have not estimated AR(1) equations.

\section{Conclusion}

Using Theil's inequality coefficient (U) based on the mean square prediction error, the paper estimated the magnitude of errors in the budgetary forecasts in India for the period ex-ante and ex-post to fiscal rules; and also decomposed the errors into biasedness, unequal variation and random components to analyze the source of error, before testing for rational expectations. The results showed that degree of errors in forecasting receipts was relatively higher than expenditure. The estimates showed that bias in errors have reduced ex-post to fiscal rules. However there is no specific trend in the forecasting errors, which reveals that budgetary estimates are made not based on adaptive expectations. Capital budget revealed more forecast errors than revenue budget. The proportion of error due to random variation has been significantly higher, which is beyond the control of the forecaster, while the errors due to bias has been negligible. The test of rational expectations revealed that neither budget estimates nor revised estimates are forecast based on the rational expectations of actual revenue and expenditure; limiting the applicability of rational expectations hypothesis in fiscal estimates in India. The efficiency of forecasts also has no significant improvement over time prior to fiscal responsibility and budget management rules in India.

\section{Acknowledgement}

The authors are respectively Associate Professor and former Project Associate at National Institute of Public Finance and Policy, India. They sincerely acknowledge the valuable comments and suggestions from Pinaki Chakraborty and the anonymous referees. Thanks are due to NIPFP Databank for providing relevant data for the paper.

\section{References}

Allan, C. M. (1965). Fiscal marksmanship, 1951-63. Oxford Economic Papers, 17(2), 317-327. https://doi.org/10.1093/oxfordjournals.oep.a040992

Asher, M. G. (1978). Accuracy of Budgetary Forecasts of Central Government, 1967-68 to 1975-76. Economic and Political Weekly, 13(8).

Auerbach, A. (2017, October). .Fiscal Policy. In the Conference on Rethinking Macroeconomics at the Peterson Institute of International Economics, Washington DC.

Bhattacharya, B. B., \& Kumari, A. (1988, June 25). Budget Forecasts of Central Government Revenue and Expenditure: A test of Rational Expectation. Economic and Political weekly, 1323-1327. (Reference to Ghosal, A. (1989). Artificial Intelligence and Applied Cybernetics. SCIMA Special Series on International Congress of Cybernetics and Systems) 
Blinder, A. S., \& Solow, R. M. (1974). Analytical Foundations of Fiscal Policy. In The Economics of Public Finance (pp. 3-115). Washington DC, Brookings.

Buiter, W. (2012). Fiscal Rules in India: Are they effective?. In Patel, U, R.,\& Ghate, C. (Ed.), The Oxford Handbook of the Indian Economy (Chapter 21, pp 621-655). Oxford University Press, Oxford, New York.

Chakrabarty, T. K., \& Wilson, V. (1982). Government of India's Budget Estimation: An Analysis of the Error Components. RBI Occasional papers, 3(2), 175-190.

Chakraborty, L. (2016). Fiscal Consolidation, Budget Deficits and Macroeconomic Activity, New Delhi, UK: Sage Publications.

Chakraborty, L., \& Shrestha, R. (2018). Fiscal marksmanship of subnational governments in India. mimeo, NIPFP.

Chakraborty, P., \& Chakraborty, L. (2018). New FRBM Framework: Time to recast Union Government Expenditure Needs. Economic and Political Weekly, 53(9).

Davis, J. M. (1980). Fiscal marksmanship in the United Kingdom, 1951-78. The Manchester school of Economic and Social Studies, 48(2), 187-202. https://doi.org/10.1111/j.1467-9957.1980.tb00719.x

Lovell, M. C. (1986). Tests of the Rational Expectations Hypothesis. The American Economic Review, 76(1), $110-24$.

Morrison, R. J. (1986). Fiscal marksmanship in the United States: 1950-83. The Manchester school of Economic and Social Studies, L(IV), 322-333. https://doi.org/10.1111/j.1467-9957.1986.tb01275.x

Muth, J. F. (1961). Rational Expectations and the theory of Price Movements. Econometrica. Journal of the Econometric Society, 29, 315-335. https://doi.org/10.2307/1909635

Nitin, K., \& Roy, R. (2016). Finance commission of India's assessments: A political economy contention between expectations and outcomes. Applied Economics, 48(2), 73-88, Routledge.

Pindyck, R. S., \& Rubinfeld, D. L. (1998). Economic Models and Economic Forecasts (4th ed.). McGraw-Hill International Editions, Economic Series.

Prest, A. R. (1975). Public Finance in Developing Countries. London, Weidenfeld and Nicolson.

Srivastava, D. K. (1975). On Forecasting Non-Corporate Income Tax Revenues in India. Public Finance/Finances Publiques, 3, 428-444.

Theil, H. (1958). Economic Forecasts and Policy. Amsterdam, North Holland.

Theil, H. (1966). Applied Economic Forecasting. Amsterdam, North Holland.

\section{Notes}

Note 1. That expectations of economic variables may be subject to error has been recognized as an important part of most explanations of the changes in the level of economic activity (Muth, 1961).

Note 2. Davis (1980) noted that budget estimates have an important 'signal effect' on outside forecasters and analysts, with particular attention in recent years focussed on the estimated borrowing requirement.

Note 3. The other factors can be wrong forecast of cost and profit of public enterprises, underestimation of cost of public programmes and projects, unanticipated increase in wage bill etc (Bhattacharyya and Kumari, 1988).

Note 4. In India, the Demands for Grants are normally taken up for consideration by Parliament in two distinct stages. First, during the recess of Parliament, by the Departmental Standing Committees attach to various Ministries/ Departments. Later, on Parliament's reassembling, the Demands are formally debated in the backdrop of the Reports of the Standing Committees and put to vote. Specific hours are allotted for these discussions. The Demands of Ministries that are to be discussed and voted are formally listed. These number only a few, and all the other Demands are finally guillotined and passed on the conclusion of the debate. 